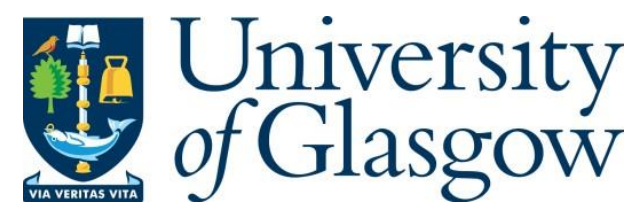

McKinney, S. J. (2018) The roots of the preferential option for the poor in Catholic schools in Luke's Gospel. International Studies in Catholic Education, 10(2), pp. 220232. (doi: 10.1080/19422539.2018.1492264)

There may be differences between this version and the published version. You are advised to consult the publisher's version if you wish to cite from it.

http://eprints.gla.ac.uk/164328/

Deposited on: 27 July 2018

Enlighten - Research publications by members of the University of Glasgow http://eprints.gla.ac.uk 


\title{
The Roots of the Preferential Option for the Poor in Catholic schools in Luke's Gospel
}

\author{
Stephen J. McKinney*: School of Education, University of Glasgow, Scotland
}

\begin{abstract}
This article argues that although the preferential option for the poor is associated with Catholic schools there is an insufficient depth in the knowledge and understanding of this concept and the implications for the aims and operation of Catholic schools. The article provides a concise overview of the care for the poor in the Vatican documents on Catholic education and a detailed analysis of Consecrated Persons and their Mission in Schools. Reflections and Guidelines (2002). This document highlights the poverty of Jesus and the mission of Jesus to the poor and the importance of the preferential option for the poor in Catholic schools. This document makes very little reference to scripture in the discussion of these themes and, consequently, this article explores the scriptural basis of the poverty of Jesus and the preferential option for the poor, drawing primarily from the gospel of Luke where the mission of Jesus for the poor and the excluded are major themes. The article concludes that the preferential option for the poor is an essential component of Christian discipleship and a fundamental tenet of Catholic schooling, though this is not always borne out in aims or practice.
\end{abstract}

\section{Keywords: Preferential option for the poor; Catholic schools; scriptural basis}

\section{Introduction}

One of the catalysts that led to the move to Liberation Theology in the Latin American Church was the irruption of the poor (Valiente, 2012). The response to the plight of the poor and the oppressed became known as the preferential option for the poor. Liberation Theology may have invented the phrase but did not invent the concept and practice of preferential option for the poor. Groody (2007) points out that the concept and practice were drawn from the gospels and Christian tradition. The use of the phrase has at times proved to be contentious, reflecting tensions between Liberation Theology and 'western' theology (Twomey, 2006). ${ }^{1}$ Arguably, these tensions have eased and the phrase is now commonly used to denote the mission of the Catholic Church to the poor and the marginalised. The phrase has recently become associated with Catholic schools and the mission of Catholic schools.

This article probes how this preferential option for the poor is articulated and manifested in Catholic schools by drawing on recent academic literature on the mission of Catholic schools to the poor and identifying some different strands. The article will then explore some of the ways in which the preferential option for the poor is discussed in Vatican documents on Catholic education, beginning with Gravissimum Educationis (1965), which discussed the idea of the care for the poor including material, emotional and spiritual poverty. The terms poverty, care for the poor and preferential option for the poor have been used and discussed in many of the subsequent Vatican documents on Catholic education, but this article focuses on an analysis of Consecrated Persons and their Mission in Schools. Reflections and Guidelines. (2002). This document addresses the poverty of Jesus and the preferential option for the poor in some detail. The analysis reveals an insufficient level of referencing of the gospel roots of the 
preferential option for the poor. This article, in an attempt to redress this imbalance, provides an examination of some of the key aspects of the poverty of Jesus and the preferential option for the poor in the gospel of Luke and reflects on the significance of these for Christian discipleship and Catholic schools.

\section{Preferential Option for the Poor and Contemporary Catholic Schools}

Over the last ten years, there has emerged an increasing body of international academic literature on the mission of Catholic schools to the poor and different strands can be discerned in this literature. One strand reflects serious anxieties about the disconnect between the history and self-proclaimed aims of some Catholic schools to serve the poor and the reality of the operation within the schools. Grace and O'Keefe (2007, p.6) raise this as a potential 'major contradiction' for Catholic schools internationally. In Australia, for example, Canavan (2009) and Benjamin (2010) have conducted research into the inclusion of children from low-income families in Catholic schools in Australia. Canavan (2009) reports that only one third of children from low-income families attend Catholic schools. Part of the difficulty is that some fees have to be paid by families to support the Catholic schools. ${ }^{2}$ Although there are measures to assist lowincome families the enrolment remains low. This is compounded by the trend of some of the wealthier Catholic families sending their children to government or non-Catholic private schools. Benjamin (2010) adds that Catholic schools enroll only one quarter of the indigenous Australian students who are Catholic.

Another strand is the situation when Catholic schools have to be completely selffunding and consequently educate the children of the wealthy. Gutiérrez $(2007,2009)$ provides the example of the Philippines where over $90 \%$ of the Catholic families cannot afford to send their children to Catholic schools. In Nigeria, the Catholic schools have to be self-supporting and so charge fees, excluding the poor (Omolade, 2009). Further, these schools perceive themselves to be in competition with the better resourced private schools. There are other examples of places where some Catholic schools include the poor and others are intentionally elitist and exclude the poor (e.g. Macau) (de Robertis and Morrison, 2009) There is a further aspect to this strand that questions if some Catholic schools express an adequate understanding of care or preferential option for the poor in their mission statements (e.g. Chile) (Cox and Imbarack, 2017).

A very interesting strand examines the role of Catholic schools that have made a radical commitment to a preferential option for the poor. There are examples such as the school founded for the poor and excluded in Barbiana, Italy by Lorenzo Milani (Grech and Mayo, 2014). Klaiber $(2007,2013)$ provides insights into the Fe y Alegría schools that originated in Peru in the 1960s. These schools are influenced by Liberation Theology and address the economic, social and psychological poverty of the children and young people. The Christo Rey schools that originated in Chicago in the 1990s provide Catholic school cultures that have been constructed to improve the life chances and social mobility of children and young people from poorer backgrounds (Aldana, 2015a). The Cristo Rey network 'serves only economically disadvantaged students' (Aldana, 2015b). These schools have been designed to be family-centred and culturally sensitive to local neighbourhoods (Murphy, 2004, p.113). ${ }^{3}$ To offset the tuition costs, the students work one day a week (Kabadi, 2015). ${ }^{4}$ These types of Catholic school are characterised by a deep commitment to the preferential option for the poor and the 
marginalised and promote an explicit and sustained solidarity between teaching staff, the pupils and their families.

A different strand is focused on the need to include Catholic Social Teaching within the curriculum in Catholic schools. This strand is concerned with intervention in the Catholic school curriculum to ensure that the children and young people have a properly formulated knowledge and understanding of the world-wide and local challenge of poverty and associated social evils. Cardinal Martino (2010, p.212) points out that Catholic schools should incorporate 'the social doctrine of the Church into their curricula'. Grace (2013) extends this and argues for the permeation of Catholic Social Teaching across the curriculum. ${ }^{5}$ Byron (2015) strenuously promotes the teaching of social justice in Catholic schools with an emphasis on poverty and hunger. Other authors explain that Catholic schools can draw from the example of inspirational figures who have advocated social justice for the poor and excluded such as Archbishop Romero (Hopper, 2014). Klaiber (2007, p. 189) points out that the Jesuit schools that educate the upper classes in Peru insist on 'inculcating social awareness in the students'. A related strand is the promotion of social justice practices in schools by ensuring there is the possibility of authentic dialogue between the pupils. This draws on the ideas of Paulo Freire (Madero, 2015; Linden, 2016).

All of these strands provide valuable insights into the ways in which the preferential option for the poor is being applied, or not applied, in Catholic schools in different parts of the world. There is still scope, however, for a deeper knowledge and understanding of the idea of the preferential option for the poor as expressed in Catholic Social Teaching, the Vatican documents on education and in the gospels. A detailed exploration of the idea of preferential option for the poor in Catholic Social Teaching and the Vatican documents is presented in a companion piece of writing in another publication $^{6}$. This article will focus on a concise overview of these ideas in the Vatican documents on education and a close examination of the idea of preferential option for the poor and its application to Catholic schools in Consecrated Persons and their Mission in Schools. Reflections and Guidelines (2002). This document has been selected for closer scrutiny because it focuses on these issues in detail. The two key issues to emerge from this document are the poverty of Jesus and his mission to the poor. The article will then explore these two issues in the gospels, with a particular emphasis on the gospel of Luke.

\section{Vatican Documents on Education and the care for the poor}

In the Vatican II and post-Vatican II era the discussion about the preferential option for the poor and Catholic schools begins with the idea of care for the poor in Gravissimum Educationis (Pope Paul VI, 1965). The final part of section 9 states that the special care for the poor is:

...in caring for the needs of those who are poor in the goods of this world or who are deprived of the assistance and affection of a family or who are strangers to the gift of faith.

Subsequent documents on Catholic education such as: The Catholic School (1977); Lay Catholics in School: Witnesses to the Faith (1982) and The Religious Dimension of Education in a Catholic School (1988); The Catholic School on the Threshold of the 
Third Millennium (1997); Consecrated Persons and their Mission in Schools (2002); Educating Together in Catholic Schools (2007) Educating to Intercultural Dialogue in Catholic Schools (2013) and Educating Today and Tomorrow: A Renewing Passion. Instrumentum Laboris (2014) discuss a variety of issues in connection to this care for the poor. These include: the nature of poverty itself, the emergence of new forms of poverty, young people being disturbed by poverty, the extent of poverty and the effects of poverty. One of the significant recurring themes in a number of the documents is that some Catholic schools that educate the children of the elite and the wealthy are a counter sign.

The educational document that addresses poverty and the preferential option for the poor in most detail is Consecrated Persons and their Mission in Schools. Reflections and Guidelines (Congregation for Catholic Education, 2002). This document highlights a number of very important points including a focus on the example of the poverty of Jesus himself (sections 6,7,10) and the preferential option for the poor (section 70-73).

The poverty of Jesus and preferential option for the poor in Consecrated Persons and their Mission in Schools. Reflections and Guidelines.

This idea of the poverty of Jesus is introduced into the document in a number of ways. First the poverty is conflated with chastity, humility and obedience, a clear reference to the kinds of vows religious will make (sections 6-7). Second the poverty is referred to as a lifestyle chosen by Jesus (section 10). The idea of choosing poverty is to follow the example of Christ: a 'freely chosen poverty' so that one can be like Christ who 'lived in the world, without being of the world' (sections 22, 26). The consecrated persons take on a 'simple and essential lifestyle, promoting a correct relationship with things and trusting in God's Divine Providence'.

While the comments in the document on the preferential option for the poor are primarily addressed to consecrated persons, they are also applicable to others engaged in Catholic education. The document provides a clear indication that the preferential option for the poor is 'at the centre of the educational programme' (section 70) and states that all Christians are called to follow the example of the Church (section 71):

Becoming the voice of the poor of the world is a challenge assumed by the Church, and all Christians should do the same.

The preferential option for the poor is conflated with section 9 of Gravissimum Educationis (section 70):

The Church does, in fact, mean to offer its educational service in the first place to "those who are poor in the goods of this world or who are deprived of the assistance and affection of a family or who are strangers to the gift of faith". Unjust situations often make it difficult to implement this choice. Sometimes, however, it is Catholic educational institutions themselves that have strayed from such a preferential option which characterized the beginnings of the majority of institutes of consecrated life devoted to teaching.

Consecrated Persons acknowledges that it may not always be possible to exercise the preferential option for the poor in unjust situations but also adds that some Catholic 
educational institutions have strayed from the option and by doing so may be operating counter to their original purpose or charism.

Consecrated Persons is a very valuable resource as a document on Catholic education that highlights the poverty of Jesus and the preferential option for the poor. However, the document shares a limitation with some of the Vatican documents that are concerned with Catholic Social Teaching. This limitation is that scripture is seldom used and when it is used, it is often used without contextualization (McLoughlin, 2012). The discussion of the poverty of Jesus in sections 6, 7, 10 and 22 of Consecrated Persons does not quote from scripture nor refer to scripture. The same is true for sections 70-73 that discuss the preferential option for the poor. This is disappointing as the poverty of Jesus and the preferential for the poor are best illustrated by use of scripture and there is a rich tradition of thinking on the preferential option for the poor that explicitly draws on scripture (Gutiérrez, 1971, 1979, 1983; Boff, 1972; Sobrino, 1976, 1981, Tamaz, 2009).

\section{The poverty of Jesus and the mission to the poor in the Gospel of Luke.}

If we are to gain a deeper knowledge and understanding of the poverty of Jesus and the preferential option for the poor, we need to return to the gospels. The three synoptic gospels share statements by Jesus about wealth and possessions such as: the wealthy man told to sell all his possessions (Mtt 19:21; Mk 10:21 Lk 18:22); the rich are unable to enter the Kingdom of God (Mtt 19:24; Mk 10:25; LK 18:25) and the Temple offerings of the wealthy and the poor widow (Mk 12:41-44; Lk 21: 1-4) (Green, 2014). The issues of the poor and the rich and the right use of material possessions are, however, major themes in the gospel of Luke (Miller, 2014). Green (2014) points out that the gospel of Luke contains some important passages about wealth, possessions and poverty that are unique to this gospel and include the Magnificat; Luke's version of the beatitudes; the rich fool; the rich man and Lazarus and Jesus and Zacchaeus. I wish to focus, then, on Luke's gospel where Jesus is born in very poor circumstances and in his mission adopts an itinerant lifestyle (Fitzmyer, 1981; LaVerdiere, 1984). This article will discuss these themes under two headings: the poverty of Jesus and the mission to the poor and the correct use of possessions. The poverty of Jesus and the mission to the poor will include: the Magnificat (1:46-55); the birth of Jesus (2:1-20); the preaching of John the Baptist (3:10-14); the scene in the synagogue at the beginning of the public ministry (4:16-21); the Beatitudes and the woes (6:20-26). The correct use of possessions will include: the parable of the rich fool (12:13-21) and the proper use of possessions, possessions come from God and are held in stewardship (12:33-34; 14:33) and an examination of contrasting attitudes in the stories of the rich man and Lazarus (16:19-31) and the story of Zacchaeus the tax collector (19:1-10).

\section{The poverty of Jesus and the mission to the poor}

Luke uses the infancy narrative as a means to introduce many of the major themes of the gospel. This includes a series of signs that indicate the poverty of Jesus and his mission to the poor. The Magnificat, Mary's hymn of praise, presents a form of role reversal for those who are proud, the powerful, the rich and for the ones they exclude: the lowly and hungry. ${ }^{7}$ It is the lowly and hungry who will be exalted (1:52) (Green, 1997; Carroll, 2014). The lowly are the ones who fear the Lord and they are the ones who are hungry and not just for food but also for God's word (Bovon, 2002). 
The birth of Jesus is the story of a child born in poor and degraded circumstances (Hogan, 1999). The placing of the child in the manger is indicative of the poverty of his earthly life and this is contrasted in Luke's gospel with the figure of the Emperor Augustus who has the authority to call the census (Green, 1997, p.125). The swaddling clothes have been interpreted as a sign of poverty but this was a normal way to dress a baby at that time and is also a reference to the birth of King Solomon who, according to the book of Wisdom (7:4-5), was nursed in swaddling clothes (Fitzmyer, 1981). ${ }^{8}$ Nevertheless, it is strikingly symbolic that the Saviour of the world should be born in temporary accommodation, in an occupied county and wrapped in swaddling clothes in a manger (Hogan, 1999). Jesus is born into a world that had a distinctive social hierarchy. Miller (2014) classifies society at that time into elites, retainers and nonelites. The elites (Roman and Jewish) would have constituted around 3\% of the population. The retainers were moderately wealthy and shared a higher social status and accounted for around $15 \%$ of the population. The vast majority of the population $(82 \%)$ lived just above, on or below subsistence level.

In Luke's gospel, the announcement of the birth of Jesus is first made to shepherds, not to the secular or religious rulers (Fitzmyer, 1981). These men represent the lowly in society and there is an association with the Old Testament and the figure of David, the shepherd boy who would become King and God's annointed. The point is that the shepherds, the lowly, are the first to hear the good news (LaVerdiere, 1984). The figure of Mary, the birth and the shepherds combine to construct a story that prefigures the solidarity that Jesus will share with the poor in his earthly ministry. The preaching of John the Baptist also includes references to poverty and the just distribution of goods (3:10-14). John's call to share clothing and food with those who have none represents the actualization of love of neighbor and the idea drawn from Deuteronomy 15:4 that nobody in Israel, in the land given by the Lord, should suffer any kind of need (Bovon, 2002).

Jesus in the synagogue in chapter four of Luke's gospel.

The scene in the synagogue in Luke chapter 4 is considered by many commentators to be programmatic for the gospel and the two-part work of Luke-Acts. (Knight, 1998; Strelan, 2008) $)^{9}$. This scene provides an overview of the mission of Jesus:

And he came to Nazareth, where he had been brought up; and he went to the synagogue as his custom was, on the Sabbath day. And he stood up to read; and there was given to him the book of the prophet Isaiah. He opened the book and found the place where it was written.

'The Spirit of the Lord is upon me, because he has anointed me to preach good news to the poor. He has sent me to proclaim release to the captives and recovering of sight to the blind, to set at liberty those who are oppressed, to proclaim the acceptable year of the Lord'.

And he closed the book, and gave it back to the attendant and sat down; and the eyes of all in the synagogue were fixed on him. And he began to say to them: 'Today this scripture has been fulfilled in your hearing.'

(Luke 4:16-21) 
The scripture reading is actually a conflation of Isaiah 61:1-2 and 58:6. This conflation is important for a number of reasons (Kimball, 1994). ${ }^{10}$ Similar to the portrayal of the poverty of Jesus in the infancy narratives, Luke positions the ministry of Jesus within some key ideas of the Old Testament. In this passage, Jesus defines his ministry in terms of Old Testament prophecy and fulfillment. A prominent feature of the pronouncement in the synagogue is the idea of 'release' (Green, 1995, p.78). This refers to the legislation in Leviticus 25 concerning the year of jubilee, the year of release. Every fiftieth year, property was to be returned to original owners, debts cancelled and slaves released. Jubilee was a reminder that 'God was sovereign over the land and that the reign of God entailed freedom from bondage' (Green, 1995, p.78). The God who saved the people from bondage in Egypt favours the poor and the oppressed (Lieu, 1997).

There is no evidence of the enactment of the jubilee year, though the prophets used the imagery of the jubilee year. In time, this acquired 'eschatological and messianic overtones' in Judaism (Kimball, p.103). According to Green, Jesus is announcing a kind of new and final Jubilee, the new era of salvation, the coming of the reign of God. This release will be from sins and through healing, release from that which excluded the person from the community (pp.78-79). This idea of the proclaiming of the good news to the poor is revisited in the scene where Jesus converses with two disciples of John the Baptist (7: 18-23) (Lieu, 1997). Jesus refers to his words and actions and they have observed him healing the sick and restoring sight to the blind. He instructs them as witnesses to tell John what they have seen and heard, including the preaching of the good news to the poor. ${ }^{11}$

The beatitudes and the woes in chapter six of Luke are addressed to the disciples and provide another example of role reversal. ${ }^{12}$ The first beatitude states that the poor are blessed for theirs is the kingdom of heaven. The second beatitude which is closely related to the first states that the hungry are blessed and they will be filled. The poor and the hungry are often presented together in the Old Testament (Green, 1997). ${ }^{13}$ They are compared to the rich and those who are full. Bovon (2002, p.225) argues that Luke and Jesus do not consider poverty to be a 'happy' condition nor an ideal situation. The happiness refers to the coming of the kingdom of God and a new reign of justice that will reinstate the poor to their rightful position.

\section{The correct use of possessions}

The parable of the rich fool (12:13-21) relates the fate of a rich man who has accumulated an abundance of crops and goods and in an internal monologue decides to create larger barns to contain his crops and possessions. While there is no evidence that his wealth has been acquired by unjust or illegal means, his fate is to die that night. His weakness is that he is too self-interested and attached to his wealth. He has neither shared his wealth nor has he been rich in God (Bovon, 2013). Later in chapter 12 in verses 33-34 this theme is revisited:

Sell your possessions, and give alms; provide yourselves with purses that do not grow old, with a treasure in the heavens that does not fail, where no thief approaches and no moth destroys. For where your treasure is, there will your heart be also. 
This passage also emphasises detachment from possessions and the sharing of resources through almsgiving. The danger of the person's relationship with their wealth and possessions is that this can be a barrier between the person and God and with other members of the community. In chapter 14, verse 33, Jesus states: 'So, therefore, whoever of you does not renounce all that he has cannot be my disciple'. The passages above from chapters 12 and 14 have been interpreted in different ways from literal to allegorical or that the complete renunciation of all possessions is for a smaller select group of Christians (Bovon, 2013). The underlying message remains that the followers of Jesus are to dedicate their lives to God, be detached from their wealth and possessions and share their resources.

Contrasting attitudes: the story of the rich man and Lazarus and the story of Zacchaeus.

The story of the rich man and Lazarus (16:19-31) and the story of Zacchaeus (19:1-10) provide contrasting examples of how the poor are, and should be, correctly treated. The rich man has all the trappings of wealth, expensive clothing and an abundance of food and ignores the poor man who lies at his gate seeking to eat what falls from the rich man's table. The two men die and face contrasting fates. The rich man in torment sees Lazarus in the bosom of Abraham, a place of honour (Fitzmyer, 1983, p. 1132). He asks 'Father Abraham' that Lazarus cool his tongue with a finger drop of water and when this is denied asks that Lazarus be sent to warn his five brothers of their potential fate. This is also denied. McLoughlin (2012) focuses on the relationship between the rich man and Lazarus. The rich man claims kinship with Father Abraham yet, even in death, the rich man does not treat Lazarus correctly. Rather, he asks that Lazarus serve his wishes rather than seeing him as a fellow child of Abraham. Even in death the rich man does not follow the teaching of the Torah and observe the relationship with the poor and the responsibility to maintain the dignity of all, even the poor and marginalised.

The story of Zacchaeus provides a contrasting example of a man behaving in the correct manner towards the poor (Green, 2014). Zacchaeus was a chief tax collector and a wealthy man. He climbed a tree to see Jesus and was told by Jesus to come down and welcome Jesus to his home. When entertaining Jesus he stated that he had given half of his goods to the poor and would restore four fold to anybody he had defrauded. ${ }^{14}$ Jesus states that salvation has come to his house for Zaccheaus is 'also a son of Abraham' (19: 9). Zacchaeus, despite being a tax collector, has demonstrated the correct attitude and treatment of the poor by treating them as neighbours and is worthy of the blessings of Abraham (Fitzmyer, 1983).

\section{The life and ministry of Jesus as Good News for the poor}

We have identified four aspects of the preferential option for the poor in Luke's gospel; (1) the example of the poverty of Jesus; (2) the roots of this preferential option in the principle of justice of responsibility to our neighbour; (3) the idea of release of all that restrains the marginalised and excluded and (4) the correct use of possessions and sharing of resources. Jesus in his life, words and deeds is the good news (Goizueta and Matovina, 2017, p. 9.). The good news is for the poor and this includes the economically poor but also all those who are excluded (Green, 1995). This is radical and uncompromising. Similarly, the idea of the rich is not restricted simply to the idea of those who possess material wealth, but a broader range of those with power and 
privilege and social inclusion. Gustavo Gutiérrez, the Liberation Theologian, draws from the radical message of the gospel, and states that the example of the poverty of Jesus and his love of the poor and excluded means that the preferential option for the poor is a sign of Christian discipleship. In fact, he calls it: an essential component of discipleship (Gutiérrez, 2009). He states that to 'be a Christian is to walk, moved by the Spirit, in the footsteps of Jesus'. This then necessarily means that the disciple follows the example of Jesus in his poverty and in the preferential option for the other, epitomized by the poor and excluded. The poverty of Jesus and the preferential option for the poor have been emphasised by Pope Benedict and Pope Francis. Pope Francis states that he wants a Church which is poor and for the poor in Evangellii Gaudium (section 198, 2013).

\section{Concluding Remarks}

How are Catholic schools to understand, articulate and exercise a preferential option for the poor? This article has argued that the response to this question needs to be rooted in scripture (and theological reflection on scripture), an understanding of the demands of this preferential option, and a deeper understanding of the implications for Christian discipleship. We have already highlighted some very good examples of the application of the preferential option to the poor in Catholic schools. There are examples of a deep commitment to the preferential option for the poor in the Barbiana, Christo Rey and Fe y Alegría schools. The rationale for these schools is the inclusion of those who are disadvantaged and marginalised. Martino, Grace and Byron have argued persuasively for the central role of Catholic Social Teaching in the curriculum of the Catholic school which would promote ideas such as responsibility for others, solidarity and sharing of resources as integral to the Christian formation. Similarly, the use of authentic dialogue, grounded in the ideas of Freire, will promote solidarity (Madero, 2015; Linden, 2016).

However, there are other more problematic examples of Catholic schools that do not include all the children from low income or indigenous backgrounds. While there are efforts made to include them, these children are effectively marginalised and excluded in two ways. First, they are excluded and marginalised in society and second, in terms of Catholic education. This is counter to the claims of care for the poor and preferential option for the poor and also the claims in Gravissimum Educationis (1965) that the church will support parents in providing a Christian education for their children, which is their right as children of God (section 23, 5). This, of course, does not necessarily entail Catholic school education, but subsequent documentation reiterates the challenges that parents face in providing this Christian education and the invaluable support of Catholic schools. ${ }^{15}$ There issues are compounded in the highly problematic examples of Catholic schools that serve the wealthy elite and Catholic schools that appear to have lost sight of their mission. These examples of Catholic schools could be said to have either strayed from the option or if this is not part of their mission, to be detached from the preferential option for the poor which is, according to Gutiérrez (2009), an essential component of Christian discipleship ${ }^{16}$ and, according to Consecrated Persons (2002), a challenge assumed by the church that is at the centre of the educational programme. 


\section{Notes}

${ }^{1}$ There were serious anxieties about: the use of Marxist analysis in Christian theology, the adoption of a more dialectical approach to theology and a perceived exclusiveness (Congregation for the Doctrine of the Faith, 1984; Phan, 2000; Naude, 2007; Torevell, 2013).

${ }^{2}$ Canavan (2009, p.177) reports that the Sydney Catholic school system receives $80 \%$ of its funding from state and federal government grants. The shortfall of $20 \%$ has to be raised through fees and levies paid by parents.

${ }^{3}$ Murphy (2004, p.111) describes the mission of the Cristo Rey Jesuit high School that opened in Pilsen-Little Village Chicago in 1996 as; 'to serve this immigrant community by providing College preparatory education in a program that would be culturally sensitive and family centred'.

${ }^{4}$ Kabadi (2015) points out the successes of the Cristo Rey network but also the divide between these schools and the more traditional Jesuit high schools in America that educate the wealthy.

${ }^{5}$ One of the seven core principles of Catholic Social teaching is, of course, the option for the poor. A very useful summary of the seven key themes of Catholic Social Teaching is provided by the United States Conference of Catholic Bishops (2017):

http://www.usccb.org/beliefs-and-teachings/what-we-believe/catholic-social-teaching/seven-themes-ofcatholic-social-teaching.cfm

${ }^{6}$ McKinney, S.J. (2018) The Preferential Option for the Poor and Catholic Schools. In Whittle, S. (ed.) Researching Catholic Education. Singapore: Springer.

${ }^{7}$ Luke describes Mary as a lowly handmaiden who is chosen to be the mother of the Lord (Luke 1:38) (Brown et. al., 1978; Fitzmyer, 1989). There are other examples of this role reversal, notably the wealthy host who is spurned by his elite peers invites the rejected: the poor, maimed, blind and lame and disrupts the system of social mores (14:21-24) (Lieu, 1997; Miller, 2014).

${ }^{8}$ Verses 4-5 of chapter 7 of the Wisdom of Solomon: I was nursed with care in swaddling cloths. For no King has had a different beginning of existence.

${ }^{9}$ Luke is the only gospel writer to refer to Jesus teaching in the synagogues as habitual (Kimball, 1994, p.101). The practice of teaching in the synagogues was continued by his post resurrection followers.

${ }^{10}$ Kimball (1994, p. 97) highlights the influence of Isaiah on Luke's gospel. There are more references to Isaiah in Luke's gospel than any other Old Testament book (84 of the 525 references in the gospel). Possibly the conflation in chapter four was an example of the gezerah shawah technique used to join two texts together to make a theological point (pp.107-108).

${ }^{11}$ Lieu (1997, p. 56) argues that as there were two of them, they would be considered to be valid witnesses (see Deuteronomy, 19:15).

${ }^{12}$ Knight (1998 p. 89) points out that Luke differs from Matthew's Sermon on the Mount by including the woes.

${ }^{13}$ See for example: Ps 107:36; Isa 32:6-7 (Green, 1997).

${ }^{14}$ Fitzmyer (1983, p.1225) notes that the four-fold restoration is consonant with some regulations in the Torah. See Exodus 21:37.

${ }^{15}$ See for Example: Lay Catholics, section 13; The Religious Dimension, sections 42-43; The Catholic School on the Threshold, section 20.

${ }^{16}$ It is also profoundly biblical. Gutiérrez (2009) states ...the expression "preferential option for the poor" is recent but its content is biblical (p.319).

Notes on Contributor: Professor Stephen McKinney is the leader of a research and teaching group in the School of Education, University of Glasgow. He is a member of the St Andrew's Foundation in the School of Education. He is the President of the Scottish Educational Research Association. His research interests include: Catholic education; faith schooling; religious education and the impact of poverty on school education.

\section{References}

Aldana, U. S. (2015a) “Does Jesus want us to be Poor?" Student Perspectives of the Religious Program at a Cristo Rey Network School. Journal of Catholic Education. 19 (1) 201-222. 
Aldana, U. S. (2015b) Introduction to the Focus Section: The Cristo Rey Network of Schools. Journal of Catholic Education. 19 (1) 178-182.

Benjamin, A. (2010) Faithful to uncertainty: Catholic schools and an evangelization of hope for the poorest. International Studies in Catholic Education. 2 (2) 148-162.

Boff, L. (1972) Jesus Christ Liberator. A Critical Christology of our Time. London: SPCK.

Bovon, F. (2002) Luke 1. Translated by C. M. Thomas. Minneapolis: Fortress Press.

Bovon, F. (2013) Luke 2. Translated by D.S. Deer. Minneapolis: Fortress Press.

Brown, R.E., Donfried, K.P. Fitzmyer, J.A. and Reumann, J. (1978) Mary in the New Testament. London: Geoffrey Chapman.

Byron, W.J. (2015) What Catholic schools can do about world hunger. International Studies in Catholic Education. 7 (2) 201-209.

Canavan, K. (2009) Catholic schools and poor and disadvantaged students: how the Sydney Catholic school system is responding to the challenge. International Studies in Catholic Education. 1 (2) 170186.

Carroll, J. T. (2014) The Gospel of Luke: A Contemporary Cartography. Interpretation: A Journal of Bible and Theology. 68 (4) 366-375.

Congregation for Catholic Education (1988) The Religious Dimension of Education in a Catholic School. http://www.vatican.va/roman_curia/congregations/ccatheduc/documents/rc_con_ccatheduc_doc_19880 407_catholic-school_en.html

Congregation for Catholic Education (1997) The Catholic School on the Threshold of the Third Millennium.

http://www.vatican.va/roman_curia/congregations/ccatheduc/documents/rc_con_ccatheduc_doc 27041 998 school2000_en.html

Congregation for Catholic Education (2002) Consecrated Persons and their Mission in Schools. Reflections and Guidelines.

http://www.vatican.va/roman_curia/congregations/ccatheduc/documents/rc_con_ccatheduc_doc_20021 028_consecrated-persons_en.html

Congregation for Catholic Education (2007) Educating Together in Catholic Schools. A Shared Mission between Consecrated Persons and the Lay Faithful.

http://www.vatican.va/roman_curia/congregations/ccatheduc/documents/rc_con_ccatheduc_doc 20070 $\underline{908 \text { educare-insieme en.html }}$

Congregation for Catholic Education (2013) Educating to Intercultural Dialogue in Catholic Schools. Living in Harmony for a Civilization of Love.

http://www.vatican.va/roman curia/congregations/ccatheduc/documents/rc con_ccatheduc doc 20131 $\underline{028 \text { dialogo-interculturale en.html }}$

Congregation for Catholic Education (2014) Educating Today and Tomorrow: A Renewing Passion. Instrumentum Laboris.

http://www.vatican.va/roman_curia/congregations/ccatheduc/documents/rc_con_ccatheduc_doc_20140 407_educare-oggi-e-domani_en.html

Congregation for the Doctrine of the Faith (1984) Instruction on Certain Aspects of the Theology of Liberation.

http://www.vatican.va/roman_curia/congregations/cfaith/documents/rc con_cfaith_doc_19840806 the ology-liberation_en.html 
Cox, C and Imbarack, P. (2017) Catholic Elite Education in Chile: Worlds Apart. In Bruno-Jofré, R. and Igelmo Zaldívar, J. (eds) Catholic Education in the Wake of Vatican II. Toronto: University of Toronto Press.

De Robertis, C. and Morrison, K. (2009) Catholic schooling, identity and social justice in Macau. International Studies in Catholic Education. 1 (2) 152-169.

Fitzmyer, J. A. (1981) The Gospel according to Luke I-IX. New York: Doubleday.

Fitzmyer, J. A. (1983) The Gospel according to Luke X-XXIV. New York: Doubleday.

Fitzmyer, J.A. (1989) Luke the Theologian, Aspects of his Teaching. London: Geoffrey Chapman.

Goizueta, R. and Matovina, T. (2017) Divine Pedagogy: Dei Verbum and the Theology of Virgilio Elizondo. Theological Studies. 78 (1) 7-24.

Grace, G. and O'Keefe, J. (2007) Catholic Schools Facing the Challenges of the $21^{\text {st }}$ Century: An Overview. In G.R. Grace and J. O'Keefe (eds) International Handbook of Catholic Education Challenges for School Systems in the $21^{\text {st }}$ Century. Dordrecht: Springer. pp.1-11.

Grace, G. (2013) Catholic social teaching should permeate the Catholic secondary school curriculum: an agenda for reform. International Studies in Catholic Education. 5 (1) 99-109.

Grech, M and Mayo, P. (2014) What Catholic educators can learn from the radical Christianity and critical pedagogy of Don Lorenzo Milani. International Studies in Catholic Education. 6 (1) 33-45.

Green, J.B. (1995) The Theology of the Gospel of Luke. Cambridge: Cambridge University Press.

Green, J. B. (1997) The Gospel of Luke. Michigan: William B. Eerdmans Publishing Company.

Green, J.B. (2014) Good News to the Poor: A Lukan Leitmotif. Review and Expositor 111 (2), 173-179.

Groody, D.G. (2007) Introduction. In Groody, D.G. (ed.) The Option for the Poor in Christian

Theology. Indiana, University of Notre Dame. pp. 1-14.

Gutiérrez, A. (2007) Catholic Schools in the Philippines: Beacons of Hope in Asia. In G. Grace and J. O'Keefe (eds) International Handbook of Catholic Handbook. Challenges for School Systems in the $21^{\text {st }}$ Century. Dordecht: Springer. pp. 709-723.

Gutiérrez, A. (2009) The preferential Option for the poor in Catholic education in the Philippines: a report on progress and problems. International Studies in Catholic Education. 1 (2) 135-151.

Gutiérrez, G. (1971) A Theology of Liberation. London: SCM Press Ltd.

Gutiérrez, G. (1979) The Power of the Poor in History. London: SCM Press Ltd.

Gutiérrez, G. (1983) We Drink from Our Own Wells. London: SCM Press Ltd.

Gutiérrez, G. (2009) The Option for the Poor arises from Faith in Christ. Theological Studies. 70. 317326.

Hogan, P. C. (1999) Christian Pharisees and the Scandalous Ethics of Jesus: Teaching Luke's Gospel at the End of the Millennium. College Literature 26 (3), 95-114.

Hopper, J. M. (2014) Risk, prophecy, truth and inspiration: a picture of Archbishop Romero in the education system of El Salvador. International Studies in Catholic Education. 6 (1) 4-13.

Kabadi, S. U. (2015) The Jesuit Social Justice Dialectic within the Cristo Rey School Model. Journal of Catholic Education. 19 (1) 183-200. 
Kimball, C.A. (1994) Jesus' Exposition of the Old Testament in Luke's gospel. Sheffield: Sheffield Academic Press.

Klaiber, J. (2007) Catholic Schools in Peru: Elites, the Poor, and the Challenge of Neoliberalism. In G.R. Grace and J. O'Keefe (eds) International Handbook of Catholic Education - Challenges for School Systems in the 21 ${ }^{\text {st }}$ Century. Dordrecht: Springer. pp. 181-193.

Klaiber, J. (2013) Fe y Alegría in Peru: solidarity and service in Catholic education. International Studies in Catholic Education. 5 (2) 144-160.

Knight, J. (1998) Luke's Gospel. Abingdon: Routledge.

LaVerdiere, E. (1984) Luke. Dublin: Veritas Publications.

Lieu, J. (1997) The Gospel of Luke. Peterborough: The Epworth Press.

Linden, I. (2016) From Freire to religious pluralism: exploring dialogue in the classroom. International Studies in Catholic Education. 8 (2) 231-240.

Madero, C. (2015) Theological dynamics of Paulo Freire's educational theory: an essay to assist the work of Catholic educators. International Studies in Catholic Education. 7 (2) 122-133.

Martino, Cardinal H.E. R.R. (2010) What Catholic schools can do to advance the cause of justice and peace in the world. International Studies in Catholic Education. 2 (2) 212-216.

McLoughlin, D. (2012) Catholic Social Teaching and the Gospel. New Blackfriars. 93, 163-174.

Miller, A. C. (2014) Bridge Work and Seating Charts: A Study of Luke's Ethics of Wealth, Poverty and Reversal. Interpretation: A Journal of Bible and Theology. 68 (4) 416-427.

Murphy, J. (2004) Civil Rights and the Latino Community: Education. In G. Cárdenas (ed.) La Causa. Civil Rights, Social Justice and the Struggle for Equality in the Midwest. Houston: Arte Público Press. pp. 107-121.

Naude, P.J. (2007) In defence of partisan justice - an ethical reflection on the "the preferential option for the poor". Verbum et Ecclesia JRG. 28 (1) 166-190.

Omolade, R. (2009) Challenges for Catholic schools in Nigeria. International Studies in Catholic Education. 1 (1) 30-41.

Phan, P.C. (2000) Method in Liberation Theologies. Theological Studies. 61, 40-63.

Pope Francis (2013) Evangelii Gaudium. http://w2.vatican.va/content/francesco/en/apost exhortations/documents/papa-francesco esortazioneap_20131124 evangelii-gaudium.html\#II.\%E2\% 80\%82The inclusion_of the poor_in_society

Pope Paul VI (1965) Gravissimum Educationis (Declaration on Christian Education). http://www.vatican.va/archive/hist_councils/ii_vatican_council/documents/vatii_decl_19651028 gravissimum-educationis en.html

Sobrino, J. (1976) Christology at the Crossroads. London: SCM Press.

Sobrino, J. (1981) The True Church and the Poor. New York: Orbis.

Strelan, R. (2008) Luke the Priest. The Authority of the Author of the Third Gospel. Aldershot: Ashgate.

Tamaz, E. (2009) Poverty, the Poor, and the Option for the poor: A Biblical Perspective. In Groody, D.G. (ed.) The Option for the Poor in Christian Theology. Indiana, University of Notre Dame. pp. 41-54.

The Holy Bible. Revised Standard Edition (1966) London: CTS. 
The Sacred Congregation for Catholic Education (1977) The Catholic School. http://www.vatican.va/roman_curia/congregations/ccatheduc/documents/rc con_ccatheduc doc 19770 $\underline{319 \text { catholic-school en.html }}$

The Sacred Congregation for Catholic Education (1982) Lay Catholics in Schools: Witnesses to Faith. http://www.vatican.va/roman_curia/congregations/ccatheduc/documents/rc_con_ccatheduc_doc_19821 015_lay-catholics_en.html

Torevell, D. (2013) Liberation, Catholic education and the nature of theology: an essay to assist Catholic teachers with problems in this field. International Studies in Catholic Education. 5 (2) 218-232.

Twomey, G.S. (2006) Pope John Paul II and the 'Preferential Option for the Poor'. Journal of Catholic Legal Studies. 45. 321-368.

Valiente, O.E. (2012) The Reception of Vatican II in Latin America. Theological Studies. 73 795-823. 